https://doi.org/10.48009/1_iis_2005_360-364

\title{
INCORPORATING ETHICS INTO MANAGEMENT INFORMATION SYSTEMS CURRICULUM IN BUSINESS SCHOOLS
}

\author{
Dr. Huei Lee, Eastern Michigan University, USA, huei.lee@emich.edu \\ Dr. Melissa Dark, Purdue University, USA, dark@ purdue.edu \\ Dr. Kuo Lane Chen, University of Southern Mississippi, USA, kuo.chen@usm.edu
}

\begin{abstract}
The purpose of this paper is to discuss important issues in incorporating ethics into the information system curriculum in the business schools. These issues include the following: What are the most important topics in teaching information ethics? What are the pedagogical methods for teaching ethical issues? Which one is the best and why?
\end{abstract}

Keywords: Information ethics, business ethics, information security, MIS curriculum

\section{INTRODUCTION}

When using information systems, information security is a major concern for businesses. In the 2004 study conducted by FBI/Computer Security Institute with 481 respondents, more than $50 \%$ of the respondents had suffered a breach of computer security. The study also reports that the two-year total for financial losses suffered by the survey respondents exceeds $\$ 3$ billion dollars $[3,11]$. To prevent possible security breaches, two types of solutions can be used; 1) installing security equipments such as anti-virus programs, firewalls and intrusion detection systems, and 2) raising the high moral standard for employees and general public. Therefore, most universities/colleges have placed increasing importance on developing information security and ethics courses for students.

Laudon and Laudon [8] defined the ethics as, "the principle of right and wrong that individuals, acting as free moral agents, use to make choices to guide their behaviors." Advancements in moral development are internal to the individual and complex in nature. Morality is a construct that is cognitive, affective, and social in nature. Enron and WorldCom's cases reveal the importance of ethics in the business schools. Because of the importance of ethics in computing, there are fair amount of papers discussing the teaching of ethics [4]. Computer ethics is listed as one of the bodies of knowledge in the undergraduate degree in computer science education in the ACM Curricula 2001 [4].

As mentioned above, ethics is a needed topic in the current day information system curriculum. However, many questions exist as to the particulars of implementing ethics in the curriculum. A partial list of these questions includes the following. While business ethics is an important topic, should information ethics be a separate topic? If so, what topics should be covered in information ethics? What information ethics courses should be offered? What are the teaching methods to teach information ethics in business schools? What issues are involved when implementing ethics courses? Are case studies an effective method for teaching ethics in business schools? How will we measure student achievement in the ethical domain? 
The primary purpose of this paper is to discuss some of the issues of incorporating ethics into information system curriculums in business schools.

This paper discusses the following issues:

1. Should the information ethics be a stand-alone course?

2. What are the most important topics in teaching information ethics?

3. If information ethics is not a stand-alone course, into which courses should it be integrated and how?

4. What are the pedagogical methods for teaching ethical issues? Which one is the best and why?

5. Which curriculum model can be used to develop the ethics curriculum?

\section{THE LEADING SCHOOLS OFFERING ETHICS COURSES}

Table 1 shows several leading schools that offer a stand-alone information ethics course. These schools include MIT, Harvard, Carnegie Mellon University, the University of Arizona, and Mississippi State University [1, 2,9]. These courses may come from different departments such as MIS, Law, or Philosophy.

Table 1. Leading Schools Which Offer Information Ethics Courses

\begin{tabular}{|c|c|c|}
\hline University/College & Course & $\begin{array}{l}\text { Department } \\
\text { Offering Course }\end{array}$ \\
\hline $\begin{array}{l}\text { Massachusetts Institute of } \\
\text { Technology (MA) }\end{array}$ & $\begin{array}{l}\text { MIT 6.805/STS085: Ethics and } \\
\text { Law on the Electronic Frontier } \\
\text { HLS: Digital Democracy } 2004\end{array}$ & $\begin{array}{l}\text { Computer Science } \\
\text { and Engineering (with } \\
\text { Harvard Law School) }\end{array}$ \\
\hline Harvard University (MA) & $\begin{array}{l}\text { MIT 6.805/STS085: Ethics and } \\
\text { Law on the Electronic Frontier } \\
\text { HLS: Digital Democracy } 2004\end{array}$ & $\begin{array}{l}\text { Harvard Law } \\
\text { School(with MIT) }\end{array}$ \\
\hline Carnegie Mellon University (PA) & Introduction to Ethics (On Line) & $\begin{array}{l}\text { Department of } \\
\text { Philosophy }\end{array}$ \\
\hline University of Arizona (AZ) & $\begin{array}{l}\text { MIS 411/511: Social, Legal, and } \\
\text { Ethical Issues of the Internet }\end{array}$ & Department of MIS \\
\hline Mississippi State University (MS) & Cyberethics & Department of MIS \\
\hline
\end{tabular}

\section{ISSUES IN INFORMATION SYSTEMS ETHICS CURRICULUM}

\section{Topics that Should Be Taught in Ethics Courses}

Although ethics contains many topics, we have compared two of the leading Management Information Systems textbooks, written by Laudon and Laudon [8] and O'Brien [10], and listed ethics topics in Table 2. 
Table 2. Possible Ethics Topics

Topics

Laudon \& Laudon

O’Brien (2005)

(2005)

\begin{tabular}{|c|c|c|}
\hline $\begin{array}{l}\text { Relationship among ethics, social, and political } \\
\text { issues in information society }\end{array}$ & $\mathrm{x}$ & \\
\hline Moral dimensions of the information age & $\mathrm{x}$ & \\
\hline $\begin{array}{l}\text { Basic concepts of responsibility, accountability, } \\
\text { and liability }\end{array}$ & $\mathrm{x}$ & $\mathrm{X}$ \\
\hline Professional codes of conduct; Ethics guidelines & $\mathrm{x}$ & $\mathrm{X}$ \\
\hline Information rights and privacy & $\mathrm{x}$ & $\mathrm{x}$ \\
\hline Property right: intellectual property & $\mathrm{x}$ & $\mathrm{X}$ \\
\hline Accountability, liability, and control & $\mathrm{x}$ & \\
\hline Systems quality & $\mathrm{x}$ & \\
\hline Legal issues in ethics; Privacy Law & $\mathrm{x}$ & $\mathrm{X}$ \\
\hline Technology ethics & & $\mathrm{X}$ \\
\hline Computer crime & $\mathrm{x}$ & $\mathrm{X}$ \\
\hline
\end{tabular}

Other similar topics are presented in other information security or MIS textbooks $[5,7,13]$. These topics reflect a managerial perspective of information ethics. Because ethics involves different disciplines such as law, political science, computer science, and information technology, the cooperation among these disciplines may be important for those schools offering ethics courses or having concentration in the information systems major.

From the above discussion, we can see there are lots of topics in ethics area? But what topics are important? We can use a model developed by Lee, Chen, Barnes, and Hsieh [6].

As mentioned by Lee et al. [6], the details of this model can be described in five steps:

Step 1. Examine the existing institutional, departmental, and/or programmatic mission statement. If none exists, it may be necessary to establish a new mission statement.

Step 2. List different competencies that fall in the ethical domain as they pertain to your mission statement.

Step 3. Distribute the questionnaire to university stakeholders (i.e., employers, graduate schools, etc.,) to determine which competencies are most desired by stakeholders.

Step 4. Delete the irrelevant competencies.

Step 5. Decide the course or what topics to be offered and develop an implementation plan. 


\section{What Teaching Methods are Good for Teaching Ethics?}

Because ethics is not a technology course, the traditional lecture method is often used. However, the purpose of ethics education is to make students believe the importance of ethics and the consequences. As was noted earlier, moral development is a complex construct comprised of cognition, affect, and socialization. Therefore, the teaching methods that are appropriate for facilitating ethical development in students are those methods that attend to the students' cognitive, affective and social development. Some of the teaching methods that are likely to allow or enable such development include: case studies $[4,12]$, team education, group discussion, and role modeling. It should be noted that while these teaching methods are better suited to teaching ethics, ultimately the responsibility for how these teaching tools are used depends upon the instructor. In other words, it would be possible to utilize a case study or a group discussion in a manner that does not attend to students cognitive, affective, and/or social development. What, then, are the ways that an instructor should attempt to use such teaching tools so that students' ethical development is holistically addressed?

In attempting to advance students' sense of ethics, any of the above teaching methods should be used in a manner that allows students to have an experience. By experience, we mean that students must be involved past the point of learning concepts, facts, or principles. Furthermore, they must be involved past the point of analysis or synthesis that is only cognitive in nature. To derive experience, students need to be involved in the content in a manner that requires them to adopt a personal stance or conviction and to defend that course of action based on their world view. Then, students must be encouraged to remain open to alternative courses of action and allowed to alter their recommended course of action based on new perspectives and information. These new perspectives might be acquired through the process of gaining new information and/or also through gaining new appreciation of existing as well as new information that emerges as a result of the social dialog inside the class, and potentially outside the class as well.

Second, the teaching tools referenced above (case studies, team education, group discussion, and role modeling) should be facilitated in a manner that allows students to understand wholes, their constituent parts, and relationships therein. Deriving meaning from experience requires that students be afforded an opportunity to grapple with isolated parts, construct a framework (or whole) that binds together or unites, in some manner, these constituent parts, only to have the framework challenged by new facts or information. As students work through these part-whole, whole-part evolving relationships, they are fraught with the tension that accompanies most change. It is in the tension and uncertainty where the greatest amount of experience is being gained and also where the ethical development is in fact occurring.

The third point that we wish to make in this paper is that students must utilize continuous active agency if they are to acquire experience that contributes to their ethical development. Students who are involved in continuous active agency as processing the content actively in the three domains previously mentioned; cognitive, affective, and social. Students must be involved in negotiating meaning from multiple perspectives. As teachers we must provide opportunities for students to experience, interact, reflect and construct their internal principles and to regulate their behavior voluntarily and through their own conviction. 


\section{CONCLUSIONS}

In this paper, the issues of how to incorporate information ethics into curriculum are discussed. Some of the possible topics in popular textbooks are discussed. Lee's model is also mentioned for developing an ethics curriculum for information systems major.

Ethics is influencing curricula in information systems. The major problem is that an additional course will increase the burden of the student credit hours when there are other important topics such as e-commerce, security, and data communications. Future research issues include 1) a survey of the business students' opinion, 2) a survey of the faculty opinion, and 3) the effectiveness of different teaching methods.

\section{REFERENCES}

1. Association for Information Systems, http://cyberethics.cbi.msstate.edu/.

2. Carnegie Mellon University, http://caae.phil.cmu.edu/Cavalier/80130.

3. CSI/FBI (2004), CSI/FBI Computer Crime and Security Survey, http://www.gocsi.com.

4. Dark, M.J., Ghafarian, A. \& Yu, J. (2004), Integrating Ethical and Social Issues into the Undergraduate Computer Science Curriculum Using Case-Based Instruction, Proceedings of the ACM SIGCSE.

5. Holden, G. (2003). Guide to Network Defense and Countermeasures. Boston, MA: Course Technology, Thomson Learning, Inc.

6. Lee, H., Chen, K., Barnes, C. \& Hsieh, C. (2005). A Mission-Based and Student-Oriented Model for E-Commerce Curriculum Development, The International Journal of Innovation and Learning, 2, 186-196.

7. Jessup, L. M. \& Valacich, J. S. (2003). Information Systems Today. Upper Saddle River, NJ: Prentice-Hall.

8. Laudon, K.C. \& Laudon, J.P. (2005). Management Information Systems $\left(9^{\text {th }}\right.$ ed). Upper Saddle River, NJ: Prentice-Hall, Inc.

9. MIT, http://www.swiss.ai.mit.edu/6095/

10. O’Brien, J. A. (2005). Introduction to Information Systems. Irwin, New York, NY: McGrawHill.

11. Panko, R. R. (2004). Corporate Computer and Network Security. Upper Saddle River, NJ: Prentice Hall.

12. Spinello, R. A. (2003). Cases Studies in Information Technology Ethics. Upper Saddle River, NJ: Prentice-Hall.

13. Whitman, M. E. \& Mattord, H. J. (2003). Principle of Information Security. Boston, MA: Course Technology, Thomson Learning Inc.

(Additional references are available on request.) 